Vol 11, Special issue 1, 2018

\title{
NEPHROPROTECTIVE ACTIVITY OF ETHANOL EXTRACT OF CURCUMA MANGGA VAL. IN PARACETAMOL-INDUCED MALE MICE
}

\author{
ROSITA $^{1}$, YUANDANI ${ }^{1,2 *}$, MARIANNE ${ }^{1}$ \\ ${ }^{1}$ Department of Pharmacology, Faculty of Pharmacy, Universitas Sumatera Utara, 5 Jalan Almamater, USU-Kampus, Indonesia. ${ }^{2}$ Centre \\ of Excellence for Green Chitosan and Advance Materials, Universitas Sumatera Utara, 5 Jalan Almamater, USU-Kampus, Indonesia. \\ Email: yuan_dani@yahoo.com
}

Received: 07 March 2018, Revised and Accepted:25 March 2018

ABSTRACT

Objective: This study aimed to evaluate nephroprotective activity of Curcuma mangga in paracetamol-induced male mice.

Methods: Male mice were divided into several groups including normal control, negative, positive, and treatment groups. Treatment groups were orally administered with $C$. mangga extract at doses of 100,200 , and $400 \mathrm{mg} / \mathrm{kg}$ bw for 7 days. On day 7 after $1 \mathrm{~h}$ of treatment, the mice were induced with paracetamol $1.05 \mathrm{~g} / \mathrm{kg}$ bw. Serum creatinine level measurement and histopathotlogy study were performed at the end of experiment.

Results: C. mangga extract was able to inhibit the increase of creatinine level and showed a significantly different from negative control (p<0.05) and did not different significantly from positive control ( $p>0.05)$. The result was supported by histopathology examination which did not show any cell damage. The nephroprotective effect of $C$. mangga was in a dose-dependent manner. C. mangga extract at dose of $400 \mathrm{mg} / \mathrm{kg}$ bw depicted the strongest nephroprotective effect.

Conclusion: $C$. mangga extract was able to protect mice kidney induced by paracetamol.

Keywords: Curcuma mangga, Serum creatinine, Histopathology.

(C) 2018 The Authors. Published by Innovare Academic Sciences Pvt Ltd. This is an open access article under the CC BY license (http://creativecommons. org/licenses/by/4. 0/) DOI: http://dx.doi.org/10.22159/ajpcr.2018.v11s1.26585

\section{INTRODUCTION}

Acute renal failure accounts for about $2 \%$ of all paracetamol poisoning events and $10 \%$ of patients with severe poisoning. In therapeutic doses, paracetamol poisoning in the kidneys occurs after the end of glutathione (due to chronic alcohol consumption, hunger, or fasting) or due to the consumption of drugs that stimulate the P-450 microsomal oxidase enzyme (e.g., anticonvulsant drugs). Acute kidney failure due to paracetamol occurs in the form of acute tubular necrosis (ATN). ATN can occur singly or together with liver necrosis [1].

The involved P-450 microsomal enzyme is found in the liver and kidneys, although it is somewhat different in each organ. The severity of kidney damage and the quantity of reactions in tissue can be significantly reduced when inhibitors of the P-450 cytochrome are available [2].

The essential oil composition of the C. mangga Val. consist of a monoterpen hydrocarbon class, consisting of 4 main components identified as mirsen (78.6\%), $\beta$-osimen (5.1\%), $\beta$-pinen (3.7\%), and $\alpha$-pinen( $2.9 \%$ ) [3]. Pharmacological studies on C. mangga revealed that this plant has immumodulatory activity and did not cause short term toxicity [4-5]. Curcumin is able to prevent kidney damage in paracetamol-induced rats [6]. Curcuma longa, Nigella sativa and Phyllanthus acidus had been proven to have nephroprotective effect [7-9]. However, the nephroprotective activity of the ethanol extract of $C$. mangga was seldom reported.

In the present study, the nephroprotective activity of ethanol extract of C. mangga on to paracetamol-induced male mice was investigated. Renal function was evaluated by measuring serum creatinine level and performing histology of the kidney.

\section{METHODS}

\section{Plant materials}

Fresh rhizomes (10 kg) of C. mangga Val. were collected from Berastagi, North Sumatera, then authenticated and deposited in Herbarium Medanense, University of Sumatera Utara (USU).

\section{Plant extraction}

The air-dried rhizomes of $C$. mangga (500 g) were soaked at room temperature in ethanol $(3 \times 3$ days). The extracts were filtered and evaporated to yield crude extracts $(38.4 \mathrm{~g}, 10.95 \% \mathrm{w} / \mathrm{w})$. The extracts were stored at $4^{\circ} \mathrm{C}$ until tested for bioassay.

\section{Nephroprotective effect}

All procedures involving the use of laboratory animals were reviewed and approved by the Animal Ethics Committee of USU. 30 male mice (25-30 g) were obtained from USU Animal Resource Unit (approval number 581/I[EPH-FMIPA/20I7]). The animals were fed mouse pellet and fresh water ad libitum for a week before experiments. Mice were randomly divided into six groups containing five animals each and all treatments were given daily for 7 days. All groups administered orally. The selected doses of C. mangga extract were based on Khorsahandi [7] who showed the nephroprotective effects of aqueous extract of $C$. longa (Zingiberaceae family) on the paracetamol (PCT)-induced nephroprotective. Mice in Group I served as the control group. Group II served as the negative group which orally administered with carboxymethylcellulose (CMC) Na $0.5 \%$. Group III served as the positive group and treated with Curcuma $^{\circledR} 58 \mathrm{mg} / \mathrm{kg}$ of body weight. Groups IV-VI, mice were treated with extract of $C$. manga 100, 200, and $400 \mathrm{mg} / \mathrm{kg}$ bw. All mice were induced by PCT $1 \mathrm{~g} / \mathrm{kg}$ of body weight. On day 8 , all animals were weighed and anesthetized with diethyl ether.

\section{Blood collection and histological study}

Blood was collected through tail of mice using a $10 \mathrm{~mL}$ syringe after $24 \mathrm{~h}$ of last treatment. Creatinine level was determined according to Jaffe's reaction on Medan Regional Health Laboratory. The kidney was obtained after the mice were sacrificed, then washed in $\mathrm{NaCl}$ to remove blood. For histological studies, the kidney was preserved in $10 \%$ formalin for biochemical analysis. The kidney was determined on Pathology Laboratory in Murni Teguh Hospital.

Statistical analysis

Statistical analysis was performed using SPSS version 17.0. Data were analyzed using Shapiro-Wilk normality test and one-way analysis of 
variance was used for comparison between groups and followed by post hoc Tukey test. Data were expressed as mean \pm SEM and $\mathrm{p}<0.05$ showed statistical significance.

\section{RESULTS AND DISCUSSION}

\section{Serum creatinine levels}

Table 1 summarizes the levels of serum creatinine after treatment with extract of $C$. mangga. The ethanol extract of $C$. mangga was administered in various doses to know the ability of $C$. mangga to neutralize kidney damage due to toxic doses of paracetamol with indicator of decreased serum creatinine levels and microscopic of renal kidney organs.

The serum creatinine levels of $C$. mangga group were significantly different with those of negative control group. The serum creatinine levels of the normal group were $0.3700 \mathrm{mg} / \mathrm{dl}$ which remained in the normal range of serum creatinine mice $(0.3-1.0 \mathrm{mg} / \mathrm{dL})[10]$.

CMC Na $0.5 \%(\mathrm{p}<0.05)$, signifying that $C$. mangga extract displayed nephroprotective effect. Of all the samples, C. mangga at dose of $400 \mathrm{mg} / \mathrm{kg}$ bw showed the highest nephroprotective activity which was comparable to those of positive control (Curcuma ${ }^{\circledR} 58 \mathrm{mg} / \mathrm{kg}$ bw). Curcuma tablet contains curcumin which has been proven to prevent kidney damage in paracetamol-induced rats [2]. The nephroprotective effect of $C$. mangga was in a dose-dependent manner. The increment of dose of $C$. mangga extract demonstrated the enhancement of nephroprotective activity.

The toxic doses of paracetamol cause significant tissue damage associated with glutathione depletion and lipid peroxidation resulting in intracellular accumulation and high reactive metabolite binding $\mathrm{N}$-acetyl-p-benzoquinone imine, liver cell damage, and often end with death. Similar effects also occur in kidney tissue [11]. This results in the accumulation of paracetamol which results in a biochemical chain reaction and culminates in acute and chronic nephropathy [12]. In addition, paracetamol also triggers apoptosis in the liver and kidney cells $[13,14]$.

The nephrotoxic effect of paracetamol toxic dose is associated with metabolic disorders of serum electrolytes, blood urea nitrogen, and serum creatinine [11]. Creatinine is derived from endogenous tissue keratin cleavage [15].

Table 1: Serum creatinine levels of male mice (mean $\pm S E M, n=5$ )

\begin{tabular}{ll}
\hline Groups & $\begin{array}{l}\text { Serum } \\
\text { creatinine level } \\
\text { (mg/dL) }\end{array}$ \\
\hline Normal & $0.37 \pm 0.57$ \\
Negative control (paracetamol) & $1.28 \pm 0.08^{*}$ \\
Positive control (curcuma $58 \mathrm{mg} / \mathrm{kg} \mathrm{bw})$ & $0.45 \pm 0.04$ \\
Treatment group (C. mangga $100 \mathrm{mg} / \mathrm{kg} \mathrm{bw})$ & $0.81 \pm 0.07^{\mathrm{a}, \mathrm{b} *}$ \\
Treatment group (C. manga $200 \mathrm{mg} / \mathrm{kg} \mathrm{bw})$ & $0.72 \pm 0.072^{\mathrm{a}, \mathrm{b} *}$ \\
Treatment group (C. mangga $400 \mathrm{mg} / \mathrm{kg} \mathrm{bw})$ & $0.53 \pm 0.08^{\mathrm{a} *}$ \\
\hline
\end{tabular}

Data were analyzed by one-way ANOVA, and followed by Tukey post hoc test. ${ }^{a} \mathrm{p}<0.05$ compared to negative control. ${ }^{\mathrm{b}} \mathrm{p}<0.05$ compared to positive control ${ }^{*} \mathrm{p}<0.05$ compared to from the normal, C. manga: Curcuma mangga
Based on data analysis of serum creatinine level performed on control group, it was found that toxic dose of paracetamol in negative control group increased serum creatinine level as compared to normal group. The result was in agreement with previous studies which showed significant increase in serum creatinine in the administration of toxic doses of paracetamol [15-16].

Creatinine is a muscle degradation product that indicates a renal dysfunction if the levels exceed the normal limits. Serum creatinine is a strong indicator of renal function and its concentration is relatively constant from day to day [17]. Curcuminoid as an antioxidant in C. mangga neutralizes kidney damage due to toxic doses of paracetamol with indicator of decreased serum creatinine levels [18].

\section{Microscopic examination}

The nephroprotective effect of $C$. mangga was supported by microscopic examination as shown in Table 2.

The histopathological changes were observed after induced by paracetamol toxic dose. The ethanol extract of $C$. mangga prevented the damages of kidney. However, dilatation of tubular lumen was still observed at dose of 100 and $200 \mathrm{mg} / \mathrm{kg}$ bw. The complete protection on kidney was observed after treatment with $C$. mangga at dose of $400 \mathrm{mg} / \mathrm{kg}$ bw as compared to positive control (Fig. 1).

Paracetamol-induced nephrotoxicity may incorporate several molecular pathways of apoptosis including removal of intracellular protective molecules and caspase activation. Although paracetamol does not alter the expression of messenger ribonucleic acid in the antiapoptotic Bcl-xL gene, it can lower Bcl-xL protein, which means it can increase apoptotic activity [19]

Paracetamol also induces the stress of the endoplasmic reticulum on renal glomeruli, which causes oxidative stress and inflammation in podocyte cells as well as mesangial glomeruli [19]. The reactive oxygen species compound, which is the result of paracetamol metabolism, can also cause glomerular damage that begins with leukocyte infiltration [21]. One of the adverse effects of paracetamol overdose is renal tubular necrosis [22]. Damage of renal organ cells in the group with ethanol extract of C. manga at dose of 100 and $200 \mathrm{mg} / \mathrm{kg}$ bw extract showed less damage as compared to control group. The ethanol extract of $C$. manga at dose of $400 \mathrm{mg} / \mathrm{kg} \mathrm{bw}$ did not showed any renal cell damage when compared with other treatment groups.

\section{CONCLUSION}

The ethanol extract of $C$. mangga was able to protect kidney damage due to toxic dose of paracetamol. The strongest protection shown by serum creatinine level was observed at dose of $400 \mathrm{mg} / \mathrm{kg}$ bw. The result was supported by histopathological study which showed no damage on kidney organ. However, further studies are required to elaborate the molecular mechanism of $C$. manga as nephroprotective agent.

\section{ACKNOWLEDGMENT}

This work was supported by University of Sumatera Utara and Murni Teguh Hospital, Indonesia.

Table 2: Effect of $C$. mangga extract on kidney

\begin{tabular}{|c|c|c|c|}
\hline Groups & Glomerular atrophy & Dilatation of lumen tubulus & Necrosis \\
\hline Normal & - & - & - \\
\hline Negative control (CMC Na 0.5\%) & ++ & ++ & ++ \\
\hline Positive control (curcuma $58 \mathrm{mg} / \mathrm{kg} \mathrm{bw}$ ) & - & - & - \\
\hline Treatment group (C. mangga $100 \mathrm{mg} / \mathrm{kg} \mathrm{bw}$ ) & - & + & - \\
\hline Treatment group (C. manga $200 \mathrm{mg} / \mathrm{kg} \mathrm{bw}$ ) & - & + & - \\
\hline Treatment group (C. mangga $400 \mathrm{mg} / \mathrm{k}$ bw) & - & - & - \\
\hline
\end{tabular}

-: Normal, +: Light, ++: Medium, CMC: Carboxymethylcellulose, C. manga: Curcuma mangga 


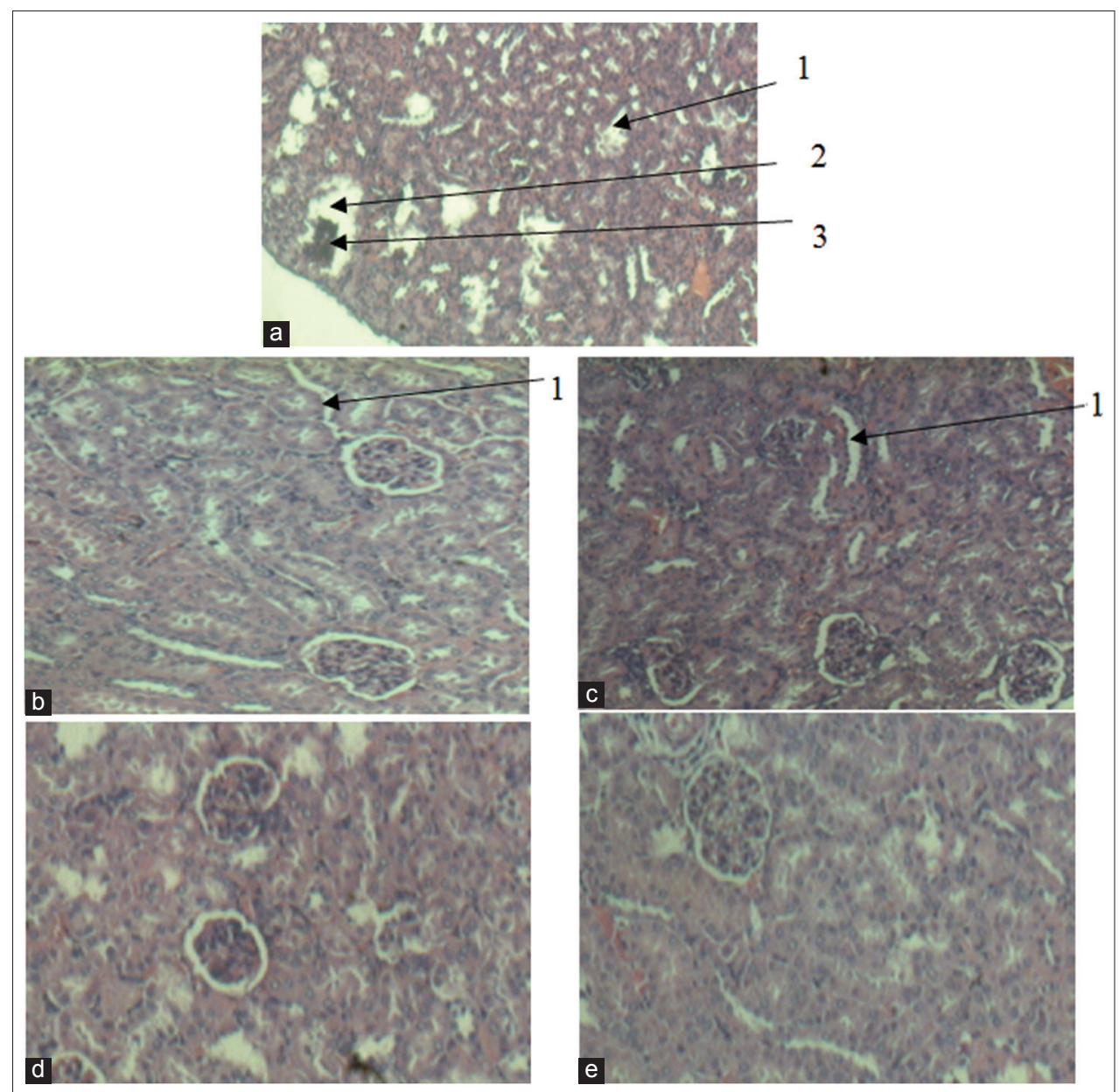

Fig. 1: Microscopic examination on kidney (a) carboxymethylcellulose Na 0.5\% (b) Curcuma mangga extract $100 \mathrm{mg} / \mathrm{kg}$ bw (c) C. mangga extract $200 \mathrm{mg} / \mathrm{kg}$ bw (d) C. mangga extract $400 \mathrm{mg} / \mathrm{kg}$ bw (e) curcuma tab. (1) Glomerular atrophy (2) Dilatation of lumen tubulus (3) necrosis

\section{REFERENCES}

1. Blakely P, McDonald BR. Acute renal failure due to acetaminophen ingestion a case report and review of the literature. J Am Soc Nephrol 1995;6:48-53

2. Mazer M, Perrone J. Acetaminophen-induced nephrotoxicity: Pathophysiology, clinical manifestations and management. J Med Toxicol 2008;4:2-6.

3. Wong KC, Chong TC, Chee SG. Essential oil of Curcuma mangga val. and zijp rhizomes. J Essent Oil Res 1999;11:349-51.

4. Yuandani and Suwarso, E. Immunomodulatory effects of ethanol extract of Curcuma mangga rhizomes in mice. Asian Journal of Pharmaceutical and Clinical Research 2017;10(9):148-50.

5. Yuandani, Suwarso, E. Acute toxicity evaluation of ethanol extract of Curcuma mangga rhizome. Asian Journal of Pharmaceutical and Clinical Research 2017;10(1):383-385.

6. Cekmen M, Ilbey YO, Ozbek E, Simsek A, Somay A, Ersoz C. Curcum in prevents oxidative renal damage induced by acetaminophen in rats. Food Chem Toxicol 2009;47:1480-4.

7. Khorshandi L. Protective effect of Curcuma longa extract on acetaminophen induced nephrotoxicity in mice. DARU J Pharm Sci 2008;16:155-9.

8. Vidya S, ramesh A, Rajashekar G, Meghana D, Nazeer SK. The nephroprotective activity of methanolic extracts of Phyllanthus acidus leaves against gentamycin-induced nephrotoxicity in experimental rodents. Int J Pharm Pharm Sci 2013;5(4):209-13.

9. Dinar NM, Pratiwi S, Kihara R, Paramita NG, Fathurrahman NR, Levita J. Hepato-nephroprotective activity of Nigella sativa oil on paracetamol-induced new zealand rabbits (oryctolagus cuniculus). Int J Pharm Pharm Sci 2017;9(11):225-28.

10. Mitruka BM. Clinical Biochemical and Hematological Reference Values in Normal Experimental Animal and Normal Humans. Philadelphia, PA: Book Medical Publisher; 1981. p. 155-9.

11. Adeneye AA, Olagunju JA, Benebo AS, Elias SO, Adisa AO, Idowu BO, et al. Nephro protective effects of the aqueous root extract of Harungana madagascariensis(1.) in acute and repeated dose acetaminophen renal injured rats. Int J Appl Res Nat Prod 2008;1:6-14.

12. Schnellman RG. Toxic responses of the kidney. In: Casarett and Doull 'S Toxicology. The Basic Science of Poisons. $6^{\text {th }}$ ed. New York: McGrawHill Medical Publishing Division; 2001. p. 86-7.

13. Ray SD, Jena N. A hepatotoxic of acetaminophen modulates expression of bcl-xl, and bcl-x5 during apoptotic and necrotic cell death of mouse liver cells in vivo. Arch Toxicol 2000;73:594-606.

14. Boulares AH, Zoltoski AJ, Stoica BA, Cuvillier O, Smulson ME. Acetaminophen induces a caspase-dependent and bcl-XL sensitive apoptosis in human hepatoma cells and lymphocytes. Pharmacol Toxicol 2002;90:38-50.

15. Palani S, Raja S, Kumar RP, Jayakumar S, Kumar BS. Therapeutic efficacy of Pimpinella tirupatiensis(apiaceae) on acetaminophen induced nephrotoxicity and oxidative stress in male albino rats. Int $\mathrm{J}$ PharmTech Res 2009;1:925-34.

16. Gosh A, Sil PC. Anti-oxidative effect of a protein from Cajanus indicusl against acetaminophen-induced hepato-nephro toxicity. J Biochem Mol Biol 2007;40:1039-49.

17. Corwin EJ. Handbook of Pathophysiology. $3^{\text {th }}$ ed. Philadelphia: Wolters Kluwer/Lippincott Williams \& Wilkins 2009.

18. Ismail AF, Asmaa AM. Renoprotective effect of curcumin on acetaminophen-induced nephrotoxicity in rats. J Chem Pharm Res 2016;8:773-9.

19. Lorz C, Justo P, Sanz AB, Egido J, Ortiz A. Role of Bcl-xL in paracetamol-induced tubular epithelial cell death. Kidney Int 2005;67:14-8.

20. Inagi R. Endoplasmic reticulum stress in the kidney as a novel mediator of kidney injury. Nephron Exp Nephrol 2009;112:e1-9.

21. Singh D, Kaur R, Chander V, Chopra K. Antioxidant in the prevention of renal disease. J Med Food 2006;9:443-50.

22. Goodman LS, Gilman A. The pharmacological basis of therapeutics. $11^{\text {th }}$ ed. USA: McGraw-Hill; 2006. p. 729-30. 